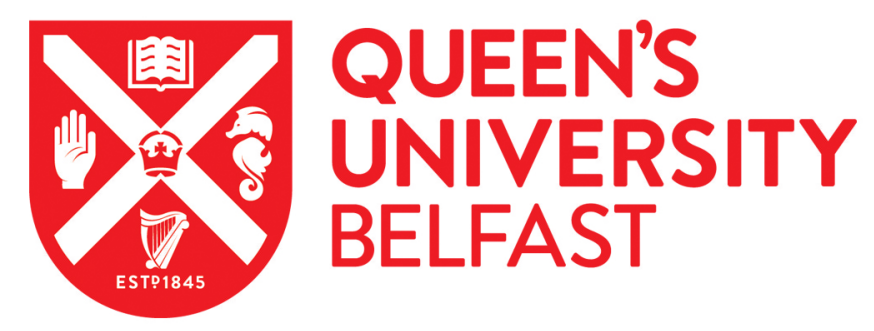

\title{
Reconstructing the Social Fabric amid On-going Violence: Attitudes toward Reconciliation and Structural Transformation in Colombia
}

Taylor, L. K., Nilsson, M., \& Amezquita-Castro, B. (2016). Reconstructing the Social Fabric amid On-going Violence: Attitudes toward Reconciliation and Structural Transformation in Colombia. Peacebuilding, 4(1), 83-98. https://doi.org/10.1080/21647259.2015.1094909

Published in:

Peacebuilding

Document Version:

Peer reviewed version

Queen's University Belfast - Research Portal:

Link to publication record in Queen's University Belfast Research Portal

\section{Publisher rights}

This is an Accepted Manuscript of an article published by Taylor \& Francis in Peacebuilding on 19 October 2016, available online: http://wwww.tandfonline.com/10.1080/21647259.2015.1094909.

\section{General rights}

Copyright for the publications made accessible via the Queen's University Belfast Research Portal is retained by the author(s) and / or other copyright owners and it is a condition of accessing these publications that users recognise and abide by the legal requirements associated with these rights.

Take down policy

The Research Portal is Queen's institutional repository that provides access to Queen's research output. Every effort has been made to ensure that content in the Research Portal does not infringe any person's rights, or applicable UK laws. If you discover content in the Research Portal that you believe breaches copyright or violates any law, please contact openaccess@qub.ac.uk. 
Running Header: RECONCILIATION IN COLOMBIA

Reconstructing the Social Fabric amid On-going Violence:

Attitudes toward Reconciliation and Structural Transformation in Colombia

\author{
Laura K. Taylor ${ }^{1}$ \\ Manuela Nilsson ${ }^{2}$ \\ Brenda Amezquita-Castro ${ }^{3}$ \\ ${ }^{1}$ Queen's University, Belfast, Northern Ireland \\ ${ }^{2}$ Linnaeus University, Sweden \\ ${ }^{3}$ University of North Carolina, Greensboro, USA
}

Correspondence concerning this paper should be addressed to Laura K. Taylor, Assistant Professor, Queen's University, Belfast, 1.taylor@qub.ac.uk.

\title{
Acknowledgements:
}

This research was funded by a Kellogg Institute Graduate Research Grant, Kroc Institute Graduate Research Summer Funding and Institute for Scholarship in the Liberals Arts Graduate Student Research Award from the University of Notre Dame. We would like to thank the many individuals who have participated in the project, including the support of the Citizens Commission for Reconciliation in the Caribbean (CCRC), the research teams at the University of Sinú, Córdoba, and CECAR, Sucre, and David Backer for his consultation. The first author is am grateful to John Paul Lederach and the members of the Peacebuilding Apprenticeship program for their guidance and support. 
RECONCILIATION IN COLOMBIA 2

\section{Abstract}

Given the increase of reconciliation processes initiated amid on-going violence, this study focuses on community reconciliation and its relation to structural transformation, or social reconstruction through reforming unjust institutions and practices that facilitate protracted violent conflict. Drawing lessons from the Caribbean coast of Colombia, mixed method analyses include eight in-depth interviews and 184 surveys. Four key dimensions of reconciliation - truth, justice, mercy, peace - are examined. In the interviews, participants prioritize reconstructing the truth and bringing perpetrators to justice as essential aspects of reconciliation. Notions of mercy and forgiveness are less apparent. For the participants, sustainable peace is dependent on structural transformation to improve livelihoods. These data, however, do not indicate how this understanding of reconciliation may relate to individual participation in reconciliation processes. Complementing the qualitative data, quantitative analyses identify some broad patterns that relate to participation in reconciliation events. Compared to those who did not participate, individuals who engaged in reconciliation initiatives report higher levels of personal experience with violence, live alongside demobilized paramilitaries, are more engaged in civic life, and express greater preference for structural transformation. The paper concludes with policy implications that integrate reconciliation and structural transformation to deepen efforts to rebuild the social fabric amid violence.

Key words: Reconciliation, structural transformation, civic engagement, political conflict, Colombia 
RECONCILIATION IN COLOMBIA 3

\section{Reconstructing the Social Fabric amid On-going Violence:}

\section{Attitudes toward Reconciliation and Structural Transformation in Colombia}

Research on reconciliation has expanded exponentially in recent decades, particularly as a means to promote peacebuilding, development, and coexistence between conflicting groups. ${ }^{1}$ Across the international, national, intergroup, and interpersonal levels, ${ }^{2}$ approaches to reconciliation range from deeply religious ${ }^{3}$ to more policy-focused. ${ }^{4}$ These latter technical approaches to reconciliation often emphasize criminal responsibility and individual rights; ${ }^{5}$ this focus highlights how the existing societal structures cannot effectively manage conflict around issues of social justice. Transformation of these social institutions is often state-led, but is also dependent on support at the community-level and individual willingness to take part in reconciliation processes. ${ }^{6}$ Particularly amid on-going violence, there is a need to examine how these factors may be integrated in order to help reweave the torn social fabric in communities affected by protracted conflict.

This article defines reconciliation as the dynamic process of reconstructing the torn social fabric that results from protracted conflict. There are two important dimensions of this definition. First, although reconciliation is often conceptualized in a post-accord period, ${ }^{7}$ this

\footnotetext{
${ }^{1}$ David Bloomfield, On Good Terms: Clarifying Reconciliation, Berghof Center for Constructive Conflict Management: Berlin, 2006; John Paul Lederach, Building Peace: Sustainable Reconciliation in Divided Societies (Washington, DC: United States Institute of Peace, 1997); Martha Minow, Between Vengeance and Forgiveness: Facing History after Genocide and Mass Violence (Boston, MA: Beacon Press, 1999).

${ }^{2}$ Ernesto Verdeja, Unchopping a Tree: Reconciliation in the Aftermath of Political Violence (Philadelphia, PA: Temple University Press, 2009).

${ }^{3}$ see John de Gruchy, Reconciliation: Restoring Justice (Minneapolis, MN: Fortress Press, 2002).

${ }^{4}$ see David Bloomfield, Teresa Barnes and Luc Huyse, eds., Reconciliation after Violent Conflict: A Handbook (Stockholm: International IDEA, 2003).

${ }^{5}$ Daniel Philpott (ed.), The Politics of Past Evil: Religion, Reconciliation, and the Dilemmas of Transitional Justice (Notre Dame, IN: University of Notre Dame Press, 2006).

${ }^{6}$ Lederach, Building Peace.

${ }^{7}$ see Timothy Longman, Phuong Pham, and Harvey M. Weinstein, 'Connecting justice to human experience: Attitudes toward accountability and reconciliation in Rwanda' in My Neighbor, My Enemy: Justice and
} 


\section{RECONCILIATION IN COLOMBIA 4}

definition is consistent with more recent research that (a) recognizes reconciliation is increasingly initiated before there is a formal end to the conflict, and (b) emphasizes that violence continues to be part of everyday life even after peace agreements have been signed. ${ }^{8}$ Reflecting the reality of protracted conflicts, this definition highlights the additional obstacles for reconciliation and social reconstruction when they are initiated within contexts of ongoing violence. ${ }^{9}$ Second, while acknowledging the importance of interpersonal relations among victims and perpetrators, as well as agreements among political elites, this article focuses on intergroup, community reconciliation processes that may be influenced by state policies. ${ }^{10}$ That is, the emphasis is on the community-level reconciliation as the intersection of individual and national efforts to recover from past harm and to build a more just society.

This research proposes that structural transformation might be an important part of, and perhaps even precondition to, collective and communal reconciliation. As one aspect of conflict transformation, ${ }^{11}$ structural transformation is a process that contributes to social reconstruction by changing the unjust structures that facilitated the violent manifestation of conflict. Structural transformation includes reforms that address the root causes of conflict and promote political, social, and economic reconstruction. For example, it aims to prevent

Community in the Aftermath of Mass Atrocity, eds., Eric Stover and Harvey M. Weinstein (Cambridge: Cambridge University Press, 2004): 206-25.

${ }^{8}$ see Cynthia Cohen, Roberto Gutiérrez, and Polly Walker, eds., Acting Together: Performance and the Creative Transformation of Conflict. Volume I: Resistance and Reconciliation in Regions of Violence (Oakland: New Village Press, 2011) and Christina Steenkamp, 'In the Shadows of War and Peace: Making Sense of Violence after Peace Accords' in Conflict, Security \& Development 11(3) (2011): 357-83.

9 Rosario Figari Layús, The Role of Transitional Justice in the Midst of Ongoing Armed Conflicts: The Case of Colombia (Potsdamer Studien zu Staat, Recht und Politik: Potsdam University, 2010); Kimberly Theidon and Paola Andrea Betancourt, 'Transiciones Conflictivas: Combatientes Desmovilizados en Colombia,' Análisis Político, 58 (2006): 92-111.

${ }^{10}$ Phil Clark, 'Negotiating Reconciliation in Rwanda: Popular Challenges to the Official Discourse of PostGenocide National Unity,' Journal of Intervention \& Statebuilding 8(4) (2014): 303-320; Kimberly Theidon, 'Entre prójimos: el conflicto armado y la politico de reconciliacion en el Perú,' Lima IEP: Estudios de la Sociedad Rural 24 (2004).

${ }^{11}$ Lederach, Building Peace. 


\section{RECONCILIATION IN COLOMBIA 5}

future violence by creating institutions and processes that increase political participation, curb corruption, reform the justice system, and dismantle social inequalities. ${ }^{12}$ Given these systemic goals, structural transformation is often initiated by the state, but relies on the cooperation of community-level actors. If successfully implemented, structural transformation may enable citizens to engage in a more equal and just social system, empowering them to have an impact on their own future. These forms of constructive civic engagement, particularly at the local level, may be at the heart of promoting collective and communal reconciliation. ${ }^{13}$

Thus, this paper explores the relation between reconciliation and structural transformation in a setting of protracted conflict. The following sections further develop these themes and apply them to the case of demobilized paramilitaries in the Caribbean coast of Colombia. This case demonstrates how initial efforts to commence reconciliation are forged even though peace has not yet been fully established. After describing the mixed methods study design and data collection, qualitative analyses examine how individuals conceptualize reconciliation and structural transformation. The findings suggest that most participants prioritize reconstructing the truth, or achieving public acknowledgement of past wrongs, and bringing perpetrators to justice as essential aspects of reconciliation. Notions of mercy for and forgiveness of perpetrators are less apparent, while discussions are peace are linked with structural transformation to improve livelihoods. However, these preferences do not necessarily map onto whether or not individuals participate in reconciliation processes. To address this question, the quantitative analyses help to identify factors that relate to

\footnotetext{
${ }^{12}$ Laura K. Taylor, 'Transitional Justice, Demobilization, and Peacebuilding amid Political Violence: Examining Individual Preferences in the Caribbean Coast of Colombia', Peacebuilding 3(1) (2015): 90-108.

${ }^{13}$ Clark, 'Reconciliation in Rwanda'.
} 
individual participation in reconciliation initiatives. Personal experience with violence, civic engagement, and support for structural transformation are all higher among those who participate in local reconciliation processes compared to those who do not. In addition, those living in a community with demobilized paramilitaries are more likely to participate in reconciliation. This complementary analytic approach is further integrated in the discussion which elaborates on the need for structural transformation as a strategy for more robust reconciliation. The paper concludes with policy implications for reweaving the social fabric in communities affected by on-going violence in Colombia.

\section{Reconciliation: Rebuilding Social Relations and Transforming Societal Structures}

With the aim of reconstructing the torn social fabric that results from protracted conflict, a number of dynamic interactions must take place. Lederach has described four inter-dependent dimensions that underlie reconciliation and the rebuilding of social relations: truth, justice, mercy, and peace. Through this analytic lens, truth reveals, clarifies and acknowledges; justice represents restitution and the search for equal rights and relationships; mercy brings acceptance, forgiveness, compassion and healing; while peace underlines the need for interdependence, sustainable livelihood, respect, and security. ${ }^{14}$ In many settings around the world, truth is pursued through the establishment of commissions, trials are often the preferred tool to achieve justice, mercy recognizes the complexity of conflict and the need for compassion for both victims and perpetrators, and peace often translates into social reconstruction that promotes security and sustainable livelihood for all. ${ }^{15}$ The emphasis on

\footnotetext{
${ }^{14}$ Lederach, Building Peace.

15 Tricia D. Olsen, Leigh A. Payne, and Andrew G. Reiter, Transitional Justice in Balance: Comparing Processes, Weighing Efficacy (Washington DC: United States Institute for Peace Press, 2010).
} 


\section{RECONCILIATION IN COLOMBIA 7}

social reforms that address impunity and hold perpetrators accountable, while at the same time recognizing the need for broader initiatives that encourage a more engaged citizenry, may indicate the importance of linking reconciliation with structural transformation.

In environments with on-going violence, however, these dimensions of reconciliation are often perceived to be contradictory. For example, amnesty is often a precondition for signing a peace agreement; although it may be seen as mercy for perpetrators, amnesty may also be considered contradictory to justice and truth. Reparations may be a result of truth seeking which reveals and acknowledges loss, as well as a sign of justice and mercy for victims by addressing the consequences of past harms. ${ }^{16}$ Thus, in each setting, a local understanding of how truth, justice, mercy, and peace may contribute to reconciliation should be established.

Even with a contextually-based understanding of these dimensions of reconciliation, individual variability in the form of experiences, attitudes, and preferences, should be taken into account, particularly as related to participation in reconciliation initiatives. Increasingly, researchers have studied how individual survivors reconcile with their perpetrators - whether community members, armed groups or state institutions. ${ }^{17}$ These findings are complemented by emerging research on the variation of individual attitudes and behaviours related to reconciliation and transitional justice. ${ }^{18}$

\footnotetext{
${ }^{16}$ Laura K. Taylor, 'JustTruth: The role of Truth Seeking in Reconciliation Following Traumatic Events and Crisis' in Memory and Trauma in International Relations: Theories, Cases, and Debates, eds., Erica Resende and Dovile Burdyte (London: Routledge Intervention Series, 2013): 107-20.

${ }^{17}$ Karen Brounéus, 'The Trauma of Truth Telling: Effects of Witnessing in the Rwandan Gacaca Courts on Psychological Health,' Journal of Conflict Resolution 54, no. 3 (2010): 408-37; Longman et al., 'Connecting Justice to Human Experience'; Juan Diego Prieto, 'Together after War While the War Goes on: Victims, Excombatants and Communities in Three Colombian Cities,' International Journal of Transitional Justice 6 (2012): 525-46.

${ }^{18}$ David Backer, 'Watching a Bargain Unravel? A Panel Study of Victims' Attitudes about Transitional Justice in Cape Town, South Africa,' International Journal of Transitional Justice 4(3) (2010): 443-456; James L. Gibson, 'Does Truth Lead to Reconciliation? Testing the Causal Assumptions of the South African Truth and
} 


\section{RECONCILIATION IN COLOMBIA 8}

Integrating across these studies, we outline possible scenarios that require further investigation. For example, individuals with greater experience of conflict-related violence may choose, or be sought out, to participate in reconciliation events. Yet, because of ongoing insecurity, those with a history of past suffering may be less likely to participate and risk public acknowledgement through community reconciliation processes. Moreover, regardless of personal histories of victimization, those living alongside former perpetrators may also be less likely to participate in reconciliation because of fear of retribution. On the other hand, due to a greater number of reintegration events, living in a community with those who have committed past wrongs may be related to more participation in reconciliation initiatives. The frequency of reconciliation events may also be related to the organizational capacity within the host communities (i.e., where demobilized perpetrators are being reintegrated). In addition, individuals who are more engaged in civic life may have greater access to and greater trust in the systems that are convening reconciliation processes.

In addition to these factors, attitudes and preferences about how society should respond to past wrongs may influence whether or not an individual participates in reconciliation or not. Based on the four dimensions of reconciliation identified above - truth, justice, mercy, and peace - it may be expected that those who want more truth-seeking may be more likely to engage in reconciliation efforts that include public acknowledgement of past wrongs. On the other hand, individuals who desire greater perpetrator accountability, including more formal forms of retributive justice, may not take part in reconciliation seeing it as a compromise to their values. Finally, although often initiated parallel and alongside

Reconciliation Process', American Journal of Political Science 48(2) (2004): 201-17; Enzo Nussio, Angelika Rettberg, and Juan E. Ugarriza, 'Victims, Nonvictims and Their Opinions on Transitional Justice: Findings from the Colombian Case,' International Journal of Transitional Justice 2015. Advance Access published April 23, 2015, doi:10.1093/ijtj/ijv006; Taylor, 'Transitional Justice'. 
reconciliation, structural transformation may serve as a foundation for collective reconciliation. By trying to reform the unjust structures that underlie protracted conflict, well-designed collective reconciliation processes may also promote political, social, and economic reconstruction. Thus, support structural transformation may be liked to participation in community-level reconciliation efforts, if those initiatives are seen as a means to address the roots causes of conflict.

Recognizing that individual motivations to participate in reconciliation may vary from person to person, however, does not negate efforts to foster more robust engagement in collective reconciliation. Uniquely situated, community reconciliation may be initiated from the outside or home-grown. For example, even top-down approaches from the state, such as amnesties, truth commissions, national days of mourning, peace marches, joint work programs, reparation payments, and social benefit programs, must be integrated into community life if they are to be successful. Moreover, initiatives emerging from and executed by local communities, such as sports events, capacity-building trainings, victimfocused workshops, often rely on the financial support of the state or international sector. ${ }^{19}$ Thus, the community-level offers an important vantage point to examine the intersection of various reconciliation initiatives in societies plagued by on-going conflict.

\section{Protracted Conflict in Colombia}

Colombia, a country mired in over 50 years of internal conflict, is an important case to enhance understanding of reconciliation amid violence. Despite on-going violence,

\footnotetext{
${ }^{19}$ Manuela Nilsson, 'Peacebuilding and Local Ownership: Who owned the Reconciliation Process in postconflict Nicaragua?' in Local Ownership in International Peacebuilding: Key Theoretical and Practical Issues, eds., Sung Yong Lee and Alpaslan Özerdem (London: Routledge, 2015).
} 
attempts to advance reconciliation in the past decade may inform current peace negotiations. For example, former President Alvaro Uribe passed the controversial Justice and Peace Law (Law 975$)^{20}$ which prioritized paramilitary demobilization, despite acknowledging the right to truth, peace, justice and reparations for the victims of the armed conflict in Colombia. ${ }^{21}$ The law offered dramatically reduced sentences to former paramilitaries who confessed their atrocities, thus serving both truth and mercy before justice. ${ }^{22}$ This process has led to few convictions; moreover, the demobilization of paramilitary members did not end violence and insecurity. Successor criminal organizations, often led by mid-level commanders of demobilized paramilitary groups, exercise territorial control in certain regions, engage in drug trafficking, and commit widespread abuses, including massacres, killings, rapes, and forced displacement. ${ }^{23}$ Although these groups have expanded operations throughout Colombia, over one-third of the demobilization of the United Self-Defence Forces (AUC) occurred in the Caribbean coast, leaving this region particularly affected by the resurgence of criminal groups. ${ }^{24}$ And, despite the creation of the National Commission of Reconciliation and Reparations to oversee, monitor and evaluate the victims' reparation, little progress was made in this regard.

Following the limitations and failures of Law 975 toward justice, truth-seeking, and

\footnotetext{
${ }^{20}$ Law 975, Ley de Justicia y Paz passed by the Congress of Colombia (June 25, 2005), http://www.eclac.cl/oig/doc/col2005ley975.pdf (accessed January 27, 2015).

${ }^{21}$ Kimberly Theidon, 'Transitional Subjects: The Disarmament, Demobilization and Reintegration of Former Combatants in Colombia', International Journal of Transitional Justice 1 (2007): 66-90.

${ }^{22}$ Human Rights Watch, 'World Report: Colombia' (2011), http://www.hrw.org/world-report-2011/worldreport-2011-colombia (accessed January 27, 2015); Amnesty International, 'Colombia: The Victims and Land Restitution Law. An Amnesty International Analysis’ (2012), http:/www.amnesty.org/en/library/asset/ AMR23/018/2012/en/9cfa36ee-95c2-406b-bea0-4d5aff522d60/amr230182012en.pdf (accessed January 27, 2015).

${ }^{23}$ Human Rights Watch, Colombia.

${ }^{24}$ International Crisis Group, 'Colombia: Towards Peace and Justice?' Latin America Report N¹6 (March14, 2006), http://www.crisisgroup.org/en/regions/latin-america-caribbean/andes/colombia/016-colombia-towardspeace-and-justice.aspx (accessed January 27, 2015).
} 
reparations, current President Juan Manuel Santos instituted the Victims and Land Restitution Law (Law 1448) ${ }^{25}$ during his first year in office. This new law aimed to promote reconciliation and peace in Colombia; yet, four years into the implementation, there are still a number of shortcomings that may deny justice to survivors of human rights violations. ${ }^{26}$ In this context, the Santos administration has also initiated peace negotiations with the major opposing guerrilla group, the Revolutionary Armed Forces of Colombia (FARC). This complex constellation of actors and initiatives poses many challenges to reconciliation, but also underlines the urgency to understand how these processes work amid on-going conflict.

\section{Study Methods}

The present study utilizes mixed methods including semi-structured interviews and quantitative surveys. Lederach's four dimensions provide a framework to understand participants' attitudes toward reconciliation; this analysis also points to the importance of structural transformation. Complementing the in-depth interviews, the surveys help to identify broad patterns of factors that vary between those individuals who participated in reconciliation initiatives and those who did not. Combining these two approaches contributes to the growing focus on individual experiences, attitudes, and preferences as they relate to participation reconciliation initiatives.

The research was conducted in collaboration with partners at the University of Sinú in Córdoba and CECAR University in Sucre during the summer of 2010. The departments of Córdoba and Sucre were selected because of the history of government abandonment, rise in

\footnotetext{
${ }^{25}$ Law 1448, Ley de Víctimas y Restitución de Tierras passed by the Congress of Colombia (June 25, 2011), http://portalterritorial.gov.co/apc-aa-files/40743db9e8588852c19cb285e420affe/ley-de-victimas-1448-ydecretos.pdf (accessed January 27, 2015).

${ }^{26}$ Amnesty International, Colombia.
} 
violence through paramilitarism and drug trafficking in the 1990s, and invasion of criminal organizations following the demobilization of paramilitaries in $2005 .{ }^{27}$ Using a purposeful sampling frame, fourteen municipalities across Córdoba and Sucre were selected to capture variability in historical levels of violence (e.g., crime and forced displacement) and civic engagement (e.g., strong community-based organizations). ${ }^{28}$

Participants for both the semi-structured interviews and the survey were selected from within these municipalities through connections within local government, social service providers and NGOs. With their assistance, participants were recruited to be representative of the population in the Caribbean coast, including sectors such as: Afro-Colombians, campesinos, churches, demobilized, displaced, indigenous, teachers, trade unionists, women, victims, and youth. ${ }^{29}$

The semi-structured interview sample included eight individuals (38\% male, $62 \%$ female) from four municipalities that represented the range of past violence and current civic engagement. Three participants lived with a spouse or partner and they all reported having between one and eight children. The quantitative survey included 184 participants (49\% male, $51 \%$ female) with an average age of 42.50 years old $(S D=14.20)$. As characteristic of the Caribbean coast ethnicity, 55\% identified as mestizo, $14 \%$ as Afro-Colombian, $10 \%$ as indigenous, and $21 \%$ did not select a race or ethnicity or chose more than one group.

For the semi-structured interviews, a series of relevant themes were identified; openended questions and follow-up probes were developed to explore each theme. For example,

\footnotetext{
${ }^{27}$ Comisión Nacional de Reparaciones y Reconciliación (CNRR), La Masacre de El Salado: Esa Guerra No Era Nuestra (Colombia: Colombo Andina de Impresos S.A., 2009).

${ }^{28}$ Victor Negrete and Miguel Garcés Pretelt, Análisis Sociopolítico de Montería y Propuestas sobre Liderazgo, Participación y Compromiso Ciudadano (Montería, Colombia: Universidad del Sinú, 2010); Laura K. Taylor, 'Relaciones entre la violencia, salud mental, participación ciudadana, y actitudes hacia la justicia transicional en la costa Caribe de Colombia' in Palobra 12 (2012): 166-83.

${ }^{29}$ Negrete and Garcés, Análisis Sociopolítico de Montería.
} 
RECONCILIATION IN COLOMBIA 13

related to reconciliation, questions included: What do you think individuals in your community and in Colombia can do to reconcile? With follow up probes such as: What would perpetrators have to do and what would victims have to do to improve their relations? Could you give some examples? Around Lederach's four dimensions of reconciliation, individuals were asked: How do you understand truth, justice, mercy, and peace? Examples of follow-up probes here included: How is truth different than justice? Does mercy have a role in responding to the conflict in your area/Colombia? How is mercy related to justice? What would peace look like in your community? Finally, the qualitative data also asked participants about concrete examples of reconciliation initiative in his/her community or municipality. When describing such initiatives, interviewers asked additional probes including: Who is responsible for promoting reconciliation? What role has/should the government play? What, if anything, should be done differently in the future and why? Of course, based on how participants answered, these questions varied to follow the flow of the interview.

Qualitative data were analysed using the Constant Comparative Method. ${ }^{30}$ In this process, data were first anonymized and divided into chunks of meaning, which are discrete, stand-alone statements that were assigned a code based on the speaker ID, gender, page, and unit number (e.g., 1-F-6-5 is ID 1, a female, and is the fifth unit on page 6). All pieces of data were labelled with a descriptive tag, or a short statement that captures the essence of the chuck of data. Throughout the rest of data analysis, each unit of data was compared to the others and sorted into provisional categories. Once all chunks of data had been assigned into a category, a rule for inclusion was written which serves to define what should, or should not,

\footnotetext{
${ }^{30}$ Pamela Maykut and Richard Morehouse, Beginning Qualitative Research: A Philosophic and Practical Guide (London: Routledge, 1994).
} 
be included in a given category. Finally, the emergent themes and patterns across categories and rules for inclusion were examine to reveal a comprehensive set of relations among the constructs in the qualitative data. A subset of these categories related to reconciliation, which included structural transformation, were used in the current study. Thus, the Constant Comparative Method allowed for analysis of themes to reveal a comprehensive set of relations in the qualitative data.

Complementing the interviews, survey measures included:

Individual exposure to political violence. Participants responded to ten questions about past exposure to violence at the individual level. ${ }^{31}$ The responses were coded $0=n o$ and $1=y e s$ if participants had experienced events such as detention without cause, forcibly displaced, and house or property destroyed. Responses were added to get an overall frequency of past exposure to violence; possible scores ranged from 0 to 10 .

Demobilized in the community. Participants responded to a single-item question that asked if there were demobilized living in their community $(0=$ no and $1=y e s)$. This question has been previously used in Colombia by the High Commission on Reintegration (ACR) ${ }^{32}$

Civic engagement. A compilation of 13 items from the World Social Values survey and the High Commission on Reintegration (ACR) survey was developed to assess the level of engagement in civil society groups. ${ }^{33}$ Participants selected among three possible responses: if they were a $2=$ active member, $1=$ inactive member or if they $0=$ do not belong to groups such as church, sports team, and community development organization. A composite

\footnotetext{
${ }^{31}$ David Backer, Anu Kulkarni, and Harvey Weinstein, West Africa Transitional Justice Project - Liberia Questionnaire (First Wave) (2007).

${ }^{32}$ Alta Consejería para la Reintegración (ACR) Social y Económica de Personas y Grupos Aliados en Armas, Presidencia de la República de Colombia (2007).

${ }^{33}$ World Social Values Survey (WSV), http://www.worldvaluessurvey.org/wvs/articles/folder published/ survey_2000/files/root_q_2000.pdf(2005) (accessed January 27, 2015); ACR 'Social y Económica'.
} 
indicator was calculated by summing the responses for each person. Higher scores indicated more active participation across more groups, with a possible range of 0 to $26(\alpha=.75)$.

Structural transformation. Participants were asked a range of questions related to transitional justice preferences designed for cross-national comparison. ${ }^{34}$ An exploratory factor analysis identified distinct, yet related subscales: perpetrator accountability (e.g., justice), public acknowledgement (e.g., truth), and structural transformation. ${ }^{35}$ In the current study, the structural transformation subscale was used and included items such as reforms that address the root causes of the conflict, promote social reconstruction, and increase victims' participation in political decision-making. Participants' support for structural transformation was expressed on a 5-point scale ranging from $0=$ strongly disagree to 4=strongly agree $(\alpha=.53)$.

Participation in reconciliation. A three-item measure, including multiple choice and open-ended questions, about participation in reconciliation processes was used. ${ }^{36}$ Participants responded $0=$ no and $1=y e s$ if they had participated in reconciliation processes and then specified who had organized the event from a list of local actors (e.g., local government, church, NGOs). Participants could select as many conveners as necessary. Finally, an openended question asked participants to describe the reconciliation initiative.

\section{Results}

Combining the qualitative and quantitative data, the findings both integrate (i.e., where the same types of questions were asked in both formats) and present complementary

\footnotetext{
${ }^{34}$ Backer et al., West Africa Questionnaire.

${ }^{35}$ Laura K. Taylor, 'Transitional Justice'.

${ }^{36}$ ACR, Social y Económica.
} 
understandings (i.e., where one set of data is more complete or insightful). This blend of integration and complementarity enables us to minimize the limitations and maximizing the potential of both qualitative and quantitative data. ${ }^{37}$ The discussion following the presentation of the main study findings further elaborates on and interprets the findings across the mixed methods findings.

\section{Life in a Violent Context}

The qualitative interviews provided many accounts of extortion, robbery, physical attack, and displacement. For example, 'when we were displaced we had been extorted, that's what made us have to leave our finca [property]. And there was also the conflict over there between the armed groups, always confrontations between the government and the armed groups, well that was what really forced us to leave our land' one man explained [1M-2-4]. The quantitative data supported this pattern of human rights abuse. Concerning the types of violence personally experienced during the conflict, approximately $33 \%$ of the survey participants had experienced political violence directly, while $64 \%$ had experienced these types of harm at the level of the nuclear family. In the survey, the most common types of violence recounted were witnessing the murder of another person (9.6\%), being personally threatened with violence $(9.4 \%)$, being detained without cause $(6.6 \%)$, and having the own property or house destroyed (5.6\%). In addition, $5 \%$ of participants had been forcibly displaced from their homes.

\section{Understanding Reconciliation: Truth, Justice, Mercy, and Peace}

\footnotetext{
${ }^{37}$ John W. Creswell, Research Design: Qualitative, Quantitative and Mixed Methods Approaches (Los Angeles: Sage Publications, 2014)
} 
Given the history of violence, over $90 \%$ of participants in both survey and interviews expressed a need to reconstruct the truth about what happened in the past in order to heal wounds and advance toward reconciliation. One participant explained that truth seeking 'would be the right thing to do, because a lot of parents still do not know where the sons are ... or what their end was' [1-M-8-44]. However, some participants expressed fear and frustration toward a truth-seeking process: 'We cannot say absolutely anything. If you say something, they will end the hearing' [7-M-7-50]. Another participant elaborated on this fear of retribution: ' when people tell the truth, they have problems. Thus, when there is fear about telling the truth in Colombia, everything remains there, hidden behind the wall. So, that is the reason why I do not think that there is fair justice' [2-F-4-22]. For participants, the lack of security related to truth-seeing was linked to another of Lederach's dimensions of reconciliation: justice.

Participants expressed the desire for both retributive justice process, such as perpetrators admitting what they have done and paying for their actions, and reparative justice, such as compensating victims' personal and material loss, in order to lay the groundwork for forgiveness and peace. Although pursuits of justice were 'very weak' [2-F-422], one participant explained, 'we want them to get punished the way they are supposed to. We want them to pay for what they did, for all the harm they have caused to us' [8-F-14138]. Another participant explained: 'We have analysed that perpetrators have been more privileged than victims. That is why we do not agree with [Law 975]. And we believe that in the case of hearings, those who committed the crime are more protected than the victims that arrive there unguarded. That is why you could say that the law is protecting perpetrators 
more than victims' [1-M-6-33]. These critiques of retributive justice processes point to the need for more inclusive efforts that also prioritize the needs of the victims.

Toward this end, participants agreed that reparations were an important step toward reconciliation since they represented a government effort to acknowledge and compensate the victims' losses. 'That [economic benefit] is something that we all need. All of us have been through a bad situation; I lost everything [when displaced], even my job' [8-F-16-158]. These themes emerge again in the discussion of how structural transformation may promote peace. However, the process of reparations through Law 975 remained a divisive issue: 'We can see that victims have not been repaired whereas perpetrators have a job, have a salary... Something unfair I would say, because a person that has murdered fifty or one hundred people has a job, while victims are still filing claims to see if they can get any kind of reparation' [1-M-7-34]. As with justice, participants reported that reparations benefit the perpetrator at the expense of the victims.

The perceived prioritization of perpetrators may influence how participants discussed mercy. Seen as compassion for perpetrators, mercy was understood and discussed in the language of forgiveness. Although participants acknowledged coexisting with the demobilized in their communities, many openly expressed that they were not ready to forgive or reconcile. 'To forgive... what can I say? In that case, I do not even know what to answer, because the truth is, I feel hatred toward those people' [8-F-10-97]. Another participant explained, 'without recognition there cannot be forgiveness [7-M-9-72]. Thus, truth and recognition of harms caused were considered important stepping-stones toward forgiveness and mercy. 
Of the four dimensions of reconciliation, the idea of peace seemed the most distant. Participants largely explained peace as the non-repetition of violence. Given links between demobilization of the paramilitaries and the rise in criminal gangs, participants still expressed concerns about future violence and the renewal of conflict. 'The government has not created a space for the public to prepare itself for the future. And, while this doesn't exist, the violence will continue... I see a darker horizon' [2-F-6-36/37]. Thus, doubts around future peace suggested a need for more public engagement and structural transformation.

\section{Reconciliation through Structural Transformation}

Structural transformation, particularly in form of starting the social and economic reconstruction of victims' livelihoods, emerged as an important factor for reconciliation in the individual interviews. Participants described how some displaced persons have accessed the limited number of local government programs to receive food, housing, and child care. 'The mayor's office was the one that gave me this territory' [4-F-3-14B] and 'provided the subsidy for my children' [4-F-5-26]. However, these forms of economic assistance were sporadic, temporary, not adequate for survival, and limited by corruption. 'In [this town] there is a problem with local governance and politics that does not let us develop. The political class here is very greedy, that is, it's a nuclear family, we could say, that has political control of the municipality and they don't let go of those assets they have' [03-F-1258]. Recognizing these barriers, participants went on to explain how sustainable peace must address existing inequalities and improve livelihoods, key objectives of structural transformation. 
Participants were united about what they considered the cornerstones of successful social reconstruction toward peace: education and jobs. 'There is peace when ... everyone has his/her job and everyone is prepared to work... When there is equality. When children are educated, leaving elementary school, finishing high school, undergraduate... and then can work... When the government realizes that it needs to create employment opportunities, or education, that is when peace is possible,' explained one participant [2-F-7-42]. Others echoed this sentiment and stressed the importance of employment opportunities particularly in the countryside [1-M-7-40]. For participants, structural transformation is reconstructing the social fabric to improve livelihoods, education, and jobs. Emphasizing the need for social and economic equality, participants suggested that political corruption and judicial systems that preference perpetrators would need to be reformed. This emergent understanding of structural transformation was also reflected in the survey items, demonstrating convergent validity across these two forms of data collection.

\section{Participation in Reconciliation Initiatives}

To complement participants' conceptualization of reconciliation explored through the qualitative data, the quantitative survey helped to identify broad patterns related to participation in reconciliation. Survey participants who had participated in a reconciliation initiative were asked to identify the convenor and to describe the event. The three most common convening institutions were the mayor's office (73\%), Social Action ${ }^{38}(73 \%)$, and the churches (70\%). The open-ended question about the type of event revealed a broad range of formats that participants considered to advance community reconciliation. For example,

\footnotetext{
${ }^{38}$ Social Action, or Acción Social, no longer in operation, was the Colombian government entity charged with managing social programs for vulnerable populations.
} 


\section{RECONCILIATION IN COLOMBIA 21}

representative responses included peace marches and processions against violence, capacitybuilding meetings and workshops, reparations and material support for victims, and a mass commemoration event for a massacre. Several respondents also noted the use of sports or recreation events among community members or with neighbouring towns as a means to promote reconciliation.

Yet, overall, only $20 \%$ of participants in the survey reported having taken part in reconciliation events. Due to the relatively low frequency of participation in reconciliation initiatives, the survey was better positioned to capture broad patterns that relate to whether or not an individual chose to participate. That is, these analyses compared respondents who reported participating in reconciliation initiatives to those who did not participate across a range of relevant factors (Table 1). Among survey participants, there were no significant differences in the number of men and women reporting participation. However, participants who attended a reconciliation initiatives had been exposed to significantly more political violence at the personal level than those who had not attended $(\mathrm{t}(137)=-3.86, p<.001 ; \mathrm{M}=$ $.29, S D=.83$ no reconciliation; $M=1.26, S D=2.05$ reconciliation) and reported that demobilized were present in their communities $(\mathrm{t}(139)=-2.18, p<.05 ; \mathrm{M}=.65, \mathrm{SD}=.48$ no reconciliation; $\mathrm{M}=.86, \mathrm{SD}=.36$ reconciliation). That is, higher levels of exposure to past political violence and living alongside the demobilized was linked with participation in reconciliation events.

\section{[ Table 1 near here ]}

In addition to risk factors, such as exposure to violence and presence of the demobilized, civic engagement was also an important factor related to participation in reconciliation. Across the survey, approximately $20 \%$ said they were not an active member in 
any community organizations. That is, across survey respondents there were relatively high levels of participation in civil society; the church (50\%), political organizations $(32 \%)$, recreational groups (25\%), and community development organizations $(25 \%)$ were most highly endorsed for active engagement. Individuals who participated in reconciliation events also reported higher levels of community engagement $(\mathrm{t}(146)=-3.39, p<.01 ; \mathrm{M}=4.85, \mathrm{SD}$ $=4.21$ no reconciliation; $\mathrm{M}=7.90, S D=5.09$ reconciliation). These findings may indicate there is a connection between civic engagement and participation in reconciliation initiative as the community level.

Finally, preferences for forms of reconciliation were also examined. Survey participants who had taken part in reconciliation processes, more strongly endorsed structural transformation, or taking steps to address the root causes of conflict, promote social reconstruction, and give victims a voice in political decision-making $(\mathrm{t}(144)=-1.78, p<.10$; $\mathrm{M}=17.84, S D=2.12$ no reconciliation; $\mathrm{M}=18.57, S D=1.41$ reconciliation). On the other hand, there were no significant differences among those who did and did not attend reconciliation events based on support for public acknowledgement of wrong doing (i.e., truth) and holding perpetrators accountable for harms caused (i.e., justice).

\section{Discussion}

This study examines reconciliation as a dynamic process of reconstructing the torn social fabric amid protracted conflict in Colombia. Using Lederach's framework to understand the qualitative interviews, there is variation across the preferences for truth, justice, mercy, and peace. Moreover, in the discussion about reconciliation, participants also emphasize the importance of structural transformation. To complement these qualitative 
findings, the survey data identify a set of factors linked with individual participation in reconciliation initiatives. That is, the contextualized understanding of reconciliation is strengthened by the broad pattern of findings that relate to whether or not individuals engage in reconciliation events. Thus, the use of mixed methods provides complementary information about reconciliation attitudes and behaviours in the Caribbean coast of Colombia.

This research underlines the importance of seeking truth and justice for people living in violent contexts, but also the particular challenges this context poses. Continued violence and distrust as well as the lack of accountability for perpetrators produces an environment of insecurity and fear of retribution, which in turn limits the dialogue about past harms and ways to move forward. Given the lack of truth seeking processes in rural areas of Colombia, ${ }^{39}$ the current findings highlight the need for renewed efforts to bring the past to light while providing protection and support for those daring to speak out, consistent with other regions of the world. ${ }^{40}$

Insecurity is also found concerning pursuits of justice. Because Law 975 is perceived to favour perpetrators at the expense of the victims, participants advocate for a more victimcentred justice in Colombia. They explain how reparations may be a means to provide justice to victims and communities. The discussion about reparations echoes other studies which found victims prioritize employment, basic sustenance, and means of livelihood, often through the return of land or property lost in displacement. ${ }^{41}$ As discussed below, these forms

\footnotetext{
${ }^{39}$ Angelika Rettberg and Juan Diego Prieto, 'Reparations of Victims of Armed Conflict in Colombia: What Do Victims Want and How Does Social Proximity with Perpetrators Affect These Needs and Expectations?' Paper presented at the $51^{\text {st }}$ Annual Convention of the International Studies Association, New Orleans, Louisiana, (February 17-20, 2010); Angelika Rettberg, 'Reparación en Colombia: ¿Qué quieren las víctimas? (Bogota: Deutsche Gesellschaft für Technische Zusammenarbeit, 2008).

${ }^{40}$ David Backer, 'Watching a Bargain Unravel?'; Karen Brounéus, 'The Trauma of Truth Telling'.

${ }^{41}$ Rettberg and Prieto, 'Reparations of Victims'.
} 
of reparations are in line with the approach to structural transformation that participants endorse.

Dissatisfaction with justice five years after demobilization may have shaped feelings toward mercy. Mercy toward through forgiveness of those who committed past crimes is not readily supported. Coexisting with the demobilized in their communities is not related to the willingness to forgive. In part, this could be related to continued threats from criminal gangs, largely constituted of former paramilitaries. Future research may be needed to better understand mercy and forgiveness amid on-going conflict.

Finally, participants' discussion about peace focused on the non-repetition of violence, which could be achieved through structural transformation. For participants, peace is a longer-term project. They articulate the need for structural transformation in the form of social and economic reconstruction of victims' livelihoods, such as education and jobs. However, participants describe current efforts to provide these forms of assistance as sporadic, limited in scope, and mired in corruption. These critiques suggest that the political reforms and increased participation in the allocation of community resources may be necessary. Despite the limitations in implementation thus far, participants still describe the need for structural transformation as an important part of long-term peace and community reconciliation.

Complementing these nuanced interview findings about how participants understood reconciliation, the surveys examined factors that may relate to participation in reconciliation activities. Here, structural transformation also is an important factor. That is, individuals who participated in reconciliation events also report greater support for structural transformation than those who did not participate. The lack of differences in support for public 
acknowledgement (i.e., truth), or perpetrator accountability (i.e., justice), suggest that there are high levels of endorsement for these approaches, regardless of whether an individual participates in reconciliation or not.

In addition, these analyses also find that past exposure to violence, the presence of demobilized in the community, and overall engagement in civic life through community development groups are higher for those who participated in reconciliation. These factors may indicate that those who had suffered from past violence, such as forced displacement, may be targeted to participate in reconciliation. Moreover, collective reconciliation initiatives may be focused in areas with reintegrated paramilitary members in an attempt to improve community relations. The findings on civic engagement may also suggest that reconciliation activities include those who are already well-connected in social networks; greater efforts may be needed to include those are less active in civil society. Together, these findings identify a range of factors that relate to individual participation in reconciliation events; these patterns should be taken into account when designing future initiatives to rebuild the social fabric of communities.

\section{Policy Implications}

Toward this end, the findings point to a number of policy implications: First integrated truth-seeking and justice processes should create safe ways for those who have suffered to share their experiences. That is, insecurity related to the continued conflict suppresses victims' participation in truth-seeking and justice initiatives. This study suggests that justice processes should be victim-centred, for example, ensuring their right to attend proceedings and hearings. Moreover, future demobilization processes should avoid 
privileging perpetrators during reintegration. Instead, support for the demobilized should be accompanied by holistic reparations that target victims' immediate and long-term needs; this integrated support is essential to promote feelings of human security for those adversely affected by war. That is, both retributive justice, understood as holding perpetrators accountable, and restorative justice, understood as reparations for victims, are necessary. Without robust participation in truth-seeking, transparent judicial proceedings, and integrated reparations, victims may be less likely to endorse forgiveness and mercy for perpetrators. Although some previous research has underlined the necessity of postponing justice for the sake of maintaining fragile peace agreements, ${ }^{42}$ overall our findings converge with more recent comparative work that emphasizes the need for inclusive truth and justice processes to promote sustainable, democratic peace. ${ }^{43}$

Second, building on the need for more comprehensive reparations, structural transformation should be recognized as constructing the foundation for reconciliation's contribution to peace. Efforts to reform social institutions through political, social, and economic reconstruction should not be isolated from other reconciliation processes. That is, reconciliation will not take root if victims feel that current structures are unjust and unequal. This research extends the debate about material and symbolic reparations,${ }^{44}$ calling for structural reparations; that is, structural transformation that includes societal changes to dismantle social inequalities, curb corruption, and increase political participation. Through implementing programs that address the root causes of the conflict and re-establish human

\footnotetext{
${ }^{42}$ See Andrew Rigby, Justice and Reconciliation: After the Violence (Boulder, CO: Lynne Rienner Publishers, 2001); Minow, Between Vengeance and Forgiveness.

${ }^{43}$ Olsen et al, Transitional Justice in Balance; Laura K. Taylor and Alexander Dukalskis, 'Old truths and new politics: Does truth commission 'publicness' impact democratization?' Journal of Peace Research, 49(5) (2012): 671-684.

${ }^{44}$ Lisa Magarrell, Reparations in Theory and Practice (International Center for Transitional Justice, 2007). Retrieved from https://www.ictj.org/sites/default/files/ICTJ-Global-Reparations-Practice-2007-English.pdf
} 
security, structural transformation offers a necessary and complementary approach to reconciliation.

Third, increasing participation in reconciliation activities may be achieved through lowering the barriers to and promoting the engagement in civil society organizations. This finding extends previous research on the important role of civil society, and particularly local groups, in peacebuilding. That is, engagement in grassroots civil society organizations empowers communities and increases local ownership in the peacebuilding process. ${ }^{45}$ The current findings demonstrate yet another possible role for civil society: advancing reconciliation. By recognizing the diverse forms of existing social networks, the state and international community should aim to partner with local groups in order to deepen reconciliation efforts and help reconstruct the social fabric of communities, ${ }^{46}$ thus adding a bottom-up perspective to the top-down initiative of structural transformation outlined above.

\section{Limitations and Future Research}

Future research should address the current study's limitations. First, although the interviews and surveys were based on a purposeful sampling strategy to balance diverse and representative perspectives, the limited sample size may have overlooked some voices. Along these lines, future research could replicate this study in other areas of the country affected by ex-combatant demobilization and continued violence. Second, given the difficulty of measurement, future studies should include additional measures, with stronger

\footnotetext{
45 Tania Paffenholz (ed.), Civil Society and Peacebuilding. A Critical Assessment (Boulder, CO: Lynne Rienner Publishers, 2010); Christine Bell and Catherine O’Rourke, 'The People's Peace? Peace Agreements, Civil Society, and Participatory Democracy,' International Political Science Review, 28(3) (2007): 293-324. Nilsson, 'Peacebuilding and Local Ownership'.

46 Taylor, 'Transitional Justice'.
} 
internal consistencies, of attitudes toward reconciliation and structural transformation. Third, this study was cross-sectional, conducted after Law 975 was enacted. Future research should track attitudes and perspectives of the same participants over time; for example, during ongoing peace negotiations with the FARC and after a settlement is reached. Longitudinal designs in other areas of the world have shown how attitudes and opinions toward reconciliation have shifted in response to changing conditions on the ground ${ }^{47}$ Finally, to fully support the generalizability of these findings, future research should include crossnational comparisons to other regions of the world engaged in reconciliation initiatives amid violent conflict.

\footnotetext{
${ }^{47}$ Backer, 'Watching a Bargain Unravel?'; Gibson, 'Does Truth Lead to Reconciliation?'.
} 


\section{Table 1}

Independent T-tests Comparing Individuals that Did and Did Not Participate in Reconciliation Initiatives $(N=184)$

\begin{tabular}{lcccc}
\hline & \multicolumn{2}{c}{$\begin{array}{c}\text { Did Not Participate in } \\
\text { Reconciliation }\end{array}$} & \multicolumn{2}{c}{$\begin{array}{c}\text { Participated in } \\
\text { Reconciliation }\end{array}$} \\
\cline { 2 - 5 } & $\mathrm{M}$ & $\mathrm{SD}$ & $\mathrm{M}$ & $\mathrm{SD}$ \\
\hline Female & 1.57 & 0.51 & 1.43 & 0.50 \\
Individual Exposure to Political Violence & 0.29 & 0.83 & $\mathbf{1 . 2 6}^{* *}$ & 2.05 \\
Demobilized in the Community & 0.65 & 0.48 & $\mathbf{0 . 8 6}^{*}$ & 0.36 \\
Civic Engagement & 4.85 & 4.21 & $\mathbf{7 . 9 0}^{* *}$ & 5.09 \\
Structural Transformation & 17.84 & 2.12 & $\mathbf{1 8 . 5 7}^{\mathrm{E}}$ & 1.40 \\
Public Acknowledgement (e.g., truth) & 22.7 & 2.19 & 22.30 & 1.80 \\
Perpetrator Accountability (e.g., justice) & 18.31 & 1.99 & 17.79 & 1.89 \\
\hline
\end{tabular}

Note: ${ }^{\mathrm{t}} p<.10,{ }^{*} p<.05,{ }^{*} p<.01,{ }^{* * *} p<.001$. Means (M) in bold represent the significantly higher values for those participants who did engage in reconciliation events, compared to those who did not (e.g., greater levels of past exposure was associated with participating in reconciliation initiatives). $\mathrm{SD}=$ standard deviations. Values reported are for equal variances assumed; all findings remain significant when equal variances not assumed. 